Barbara Štebih Golub

Institut za hrvatski jezik i jezikoslovlje

Zagreb

bstebih@ihjj.hr
Data przesłania tekstu do redakcji: 01.06.2016

Data przyjęcia tekstu do druku: 15.02.2017

\title{
Stopljenice u medijskome i reklamnome diskursu suvremenoga hrvatskog jezika
}

AвStRACt: Štebih Golub Barbara, Stopljenice u medijskome i reklamnome diskursu suvremenoga hrvatskog jezika (Blends in Media and Advertising Discourse in Contemporary Croatian Language). "Poznańskie Studia Slawistyczne" 13. Poznań 2017. Publishing House of the Poznań Society for the Advancement of the Arts and Sciences, pp. 195-208. ISSN 2084-3011.

The paper deals with blends - compound words which are formed by blending of form and meaning of two (or more) words - in contemporary Croatian language. Due to their structural peculiarity and expressiveness, they have been very frequent in Croatian language of commercials and media during the last decade or so. On the basis of corpus collected from Croatian commercials, electronic publications and news portals from 2009 to 2016, the paper analyses the structure of blends, their meanings and their place in the lexical system of Croatian language.

KEYwORDs: blends; language of commercials; language of the media; structures; meanings; occasionalisms

\section{Uvod}

Unazad desetak godina u hrvatskome su jeziku učestale tvorenice nastale stapanjem dijelova (najčešće) dviju riječi, pri čemu do stapanja dolazi i na razini oblika i na značenjskoj razini. Kako je glavnim obilježjem stopljenica izrazita ekspresivnost, veoma su česte u jeziku reklama i medija.

U ovome će se radu taj novi tip tvorenica analizirati s obzirom na njihovu strukturu, značenje i status u leksiku hrvatskoga jezika.

Korpus za naše istraživanje čine stopljenice ekscerpirane iz hrvatskih promidžbenih poruka, elektroničkih izdanja dnevnih novina (Jutarnji list, Novi list, Večernji list, 24 sata) i s informativnih portala (www.dnevno.hr, www.halter.hr, www.index.hr, www.dragovoljac.com, www.net.hr, www. tportal) u razdoblju od 2009. do 2016. godine. 


\subsection{Općenito o stopljenicama}

Nazivom stopljenice prema Ivanu Markoviću (2013, 93) označujemo riječi nastale kombiniranjem i fuzioniranjem nemorfemskih dijelova dviju (rijetko više) punoznačnica.

Koncept umetanja, stapanja, spajanja - kako formalnoga tako i sadržajnoga $-u$ temelju je naziva za takve tvorenice i $u$ drugim jezicima. Primjerice u njemačkome nalazimo nazive Kofferwort, Portmanteauwort, Wortkreuzung, Wortmischung, Wortverschmelzung, Zusammenziehung, $\mathrm{u}$ engleskome amalgam, blend, contamination, crossing of words, fusion, hybrid, port-manteau word, telescoped word, a u francuskome contamination, mot valise. U hrvatskome se za same tvorenice rabe nazivi slivenice i stopljenice, a za tvorbeni postupak kojim nastaju sažimanje, kontaminacija, stapanje i leksička fuzija.

Iako stopljenice u hrvatskome jeziku, osobito razgovornome (npr. $f i$ guar $<$ fićo + jaguar, škodilak $<$ škoda + kadilak, doviđorno $<$ doviđenja + tal. buon giorno), ni do sada nisu bile nepoznate, posljednjih desetak godina dolazi do njihove hipertrofije, i to ponajprije pod utjecajem engleskoga jezika, pa se možemo složiti s Rankom Bugarskim $(2002 ; 2013)$ da je riječ o sociolingvistički motiviranome procesu.

Naime u engleskome se jeziku stopljenice (engl. blends) javljaju već od dvadesetih godina prošloga stoljeća $($ brunch $<$ breakfast + lunch, motel $<$ motor + hotel, rockabilly $<$ rock and roll + hillbilly, smog $<$ smoke + fog), a sam je tvorbeni postupak stapanja (engl. blending) čest i uobičajen. Pod utjecajem engleskoga kao globalnoga jezika, a nesumnjivo i zbog novih izražajnih mogućnosti koje takve tvorenice pružaju, stapanje se proširilo i u drugim svjetskim jezicima: primjere stopljenica nalazimo $\mathrm{u}$ francuskome ${ }^{1}$ (musicassette $<$ musique + cassette, franglais $<$ français + anglais, Avantime $<$ fr. avant + time $^{2}$ Eauscar $<$ fr. eau + engl. Oscar $\left.{ }^{3}\right)$, talijanskome (fantascienza $<$ fantasia + scienza, narcotraffico $<$ narcoti$c i+$ traffico, cartolibreria $<$ cartoleria + libreria $),{ }^{4}$ njemačkome jeziku

\footnotetext{
${ }^{1}$ Primjeri prema Muhvić-Dimanovski (2005, 100).

${ }^{2}$ Riječ je o tipu Renaultova automobila. Zanimljiva je i jer je riječ o englesko-francuskome hibridu.

${ }^{3}$ Riječ je o nazivu nagrade za najbolju vodu u ambalaži.

${ }^{4}$ Primjeri prema Muhvić-Dimanovski $(2005,101)$.
} 
(Medizyniker $<$ Mediziner + Zyniker, Ostalgie $<$ Osten + Nostalgie, Stagflation $<$ Stagnation + Inflation)...

Da znatno povećanje broja stopljenica nije samo pojava koja se javlja u suvremenome hrvatskome jeziku već i u drugim slavenskim jezicima, svjedoče slavistički radovi nastali posljednjih petnaestak godina.

Pišući o takvim tvorenicama, R. Bugarski $(2002 ; 2013)$ rabi sintagme „reči skrivalice” i „leksičke skrivalice” te ističe da su upravo zbog svojega šaljivoga karaktera osobito česte u jeziku medija i reklama. Definira ih kao riječi gdje se „slivanjem prvoga dela jedne reči i drugoga dela druge obrazuje treća reč, koja i semantički predstavlja kombinaciju tih dveju" (Bugarski, 2002, 219).

Elena Koriakowcewa (2006, 122-131) osvrće se na odnos oblika i značenja takvih tvorenica i rabi termin rječotvorna kompresija kako bi naznačila da pri tvorbi stopljenica dolazi do komprimiranja i forma i sadržaja riječi čiji se dijelovi stapaju.

Istraživanja Irene Stramljič Breznik (2010a, 2010b, 2012) pokazuju da su stopljenice česte i u slovenskome jeziku reklama i medija ponajprije zbog svoje ekspresivnosti i efekta začudnosti koji izazivaju.

O plodnosti toga novoga tvorbenog načina svjedoči nedavno objavljen Hrvatski rječnik stopljenica ${ }^{5}$ autora Ivana Markovića, Ivane Klindić i Ive Borković koji obaseže više od 5000 takvih riječi iz veoma raznorodnih vrela: od publicistike preko znanstvenih i leksikografskih radova do blogova i reklama. Dakle stopljenice kao tvorenice u kojima dolazi do stapanja dviju (ili više) riječi, kako na razini forme tako i na razini sadržaja, posljednjih se desetljeća pod utjecajem engleskoga učestalije javljaju u jezicima svijeta, pa tako i u hrvatskome jeziku. ${ }^{6}$ Kako je riječ o ekspresivnome leksiku, najčešće su u jeziku medija ili reklama.

\subsection{Strukture stopljenica}

Za razliku od drugih rječotvorbenih načina u hrvatskome jeziku (izvođenje, slaganje) stapanje ne ovisi o morfemima, tj. ne počiva na morfemskoj raščlambi riječi i ulančavanju morfema, nego se riječi doživljavaju

\footnotetext{
${ }^{5}$ Rječnik je objavljen nekoliko mjeseci nakon što je ovaj rad dovršen i predan, pa nije poslužio kao izvor za ekscerpciju našega korpusa.

${ }^{6}$ Bagić (2015) njihovo pojavljivanje čak smatra pouzdanim znakom vremena.
} 
kao fonetski materijal koji se može rezati i spajati u „tvorbeni krpež” (Marković, 2009, 224). ${ }^{7}$ Dakle proizvoljno se izdvajaju dijelovi dviju ili rjeđe više riječi koji se potom spajaju. Pri tome nerijetko dolazi i do preklapanja fonetskog materijala koji pripada riječima koje se stapaju, pa je unutar stopljenice teško jasno odrediti koji dio potječe od koje riječi.

U našem su korpusu potvrđene sljedeće strukture stopljenica:

a) stapaju se prvi dio prve i drugi dio druge riječi, tj. A (ab) + B (cd) $>$ C (ad). ${ }^{8}$ npr. Sretan Čoksić! $\left(<\right.$ Čoksa + Božić),${ }^{9}$ Dikolores (Dikan + Dolores $),{ }^{10}$ katolibanija (< katolici + talibanija), Viktator (< Viktor Orban + diktator);

b) stapaju se prvi dio prve riječi i cijela druga riječ, tj. A (ab) + B (cd) $>$ C (acd), npr. Karapozaić (Karamarko + Pozaić), Karamarkić(ka) (Karamarko + Markićka), ${ }^{11}$ karamućak (Karamarko + mućak), Karavaso (Karamarko + Milijan Vaso Brkić);

c) stapa se cijela prva riječ $\mathrm{s}$ drugim dijelom druge riječi, tj. A (ab) + $\mathrm{B}(\mathrm{cd})>\mathrm{C}(\mathrm{abd})$, npr. baumaximalno $(<$ Baumax + maksimalno $)$, freelika $(<$ free + prilika $)$, freestupačan $(<$ free + pristupačan $)$, Ledonardo $(<$ Ledo + Leonardo);

d) stapaju se cijela prva i cijela druga riječ pri čemu se dio fonetskoga materijala obiju riječi preklapa, A $(\mathrm{ab})+\mathrm{B}(\mathrm{cd})>\mathrm{C}(\mathrm{abcd})$, npr. kerumobolno (Kerum + umobolno $)$, sprinternet $(<$ sprint + internet $)$.

$\mathrm{Na}$ temelju našega korpusa može se zaključiti da u hrvatskome jeziku obično dolazi do stapanja dviju imenica, no zabilježeni su i slučajevi stapanja stranoga pridjeva i imenice, npr. freelika $<($ engl. free + prilika $)$, freestupačan (< engl. free + pristupačan).

Osobito u jeziku reklama čest dio stopljenica ime je robne marke ili tvrtke, npr. Sretan Čoksić (< Čoksa + Božić), baumaximalno $(<$ Baumax + maksimalno), Onetastičan (<City Centar One + fantastičan).

${ }^{7}$ Isti autor stopljenice naziva i „riječima hermafroditima” aludirajući na taj način na klasičnu tradiciju (Hermafrodit kao sin Hermesa i Afrodite).

${ }^{8}$ Riječ je o modelu koji Bugarski (2002, 223) naziva klasičnim.

${ }^{9}$ Riječ je o predbožićnom reklamnom sloganu hrvatske tvornice slatkiša Kraš u kojem se stapa naziv vrste čokolade Čoksa s imenom blagdana Božić.

${ }^{10}$ Riječ je o poznatome paru iz hrvatskoga javnoga života. O stopljenici će još biti riječi u dijelu posvećenome značenju.

${ }^{11}$ Iz ovoga je primjera vidljivo kako se dijelovi riječi koje se stapaju glasovno mogu preklapati (Karamarko + Markićka), pa ponekad nije moguće jasno odrediti koji dio stopljenice potječe od koje riječi sastavnice. 
Nerijetke su i stopljenice koje sadrže osobno ime poznate osobe iz javnoga života ili se čak sastoje od dvaju imena, npr. Kerumarko (Željko Kerum + Tomislav Karamarko), Karavaso (Tomislav Karamarko + Milijan Vaso Brkić), Karamarkićka (Tomislav Karamarko + Željka Markić(ka)). Naše je istraživanje pokazalo da se kao dijelovi stopljenica - uz rijetke primjere imena osoba iz svijeta „bogatih i slavnih” (npr. Dikolores) najčešće javljaju imena političara (Rankozy < Ranko Ostojić + Sarkozy,

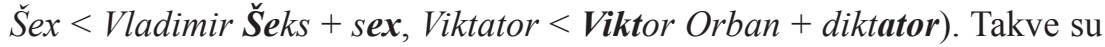
tvorenice vezane za publicistički stil.

\subsection{Značenje stopljenica i njihova stilska vrijednost}

Već smo spomenuli da se stapanje odvija i na razini forme i na razini sadržaja. Ranko Bugarski (2002, 2013) pišući o stopljenicama u srpskome jeziku, ističe da je riječ o tvorenicama šaljivoga, šeretskoga karaktera.

Ta tvrdnja vrijedi i za stopljenica u hrvatskome jeziku. Primjerice stopljenicama figuar (< fićo + jaguar) i škodilak $(<$ škoda + kadilak) maloga se fiću izjednačuje s luksuznim jaguarom, a skromnu škodu s cadillacom. Rijetke su stopljenice - primjerice radoholičar $(<\text { rad }+ \text { alkoholičar })^{12}-$ koje su postale dijelom stilski neobojenoga leksika hrvatskoga jezika.

Krešimir Bagić (2015) zaključuje da je značenje stopljenice nadređeno značenjima polaznih riječi i da je stopljenica „ekspresivan leksem koji karakteriziraju enigmatičnost, ludičnost, humornost i kritički potencijal. Iza nje u pravilu proviruju namjera i svjetonazor, zaigrani tvorac ili osviješteni korisnik. Stopljenica je izrazito vezana za kontekst, prigodu, događaj, osobu ili (kada je književnost u pitanju) osobit karakter fikcionalnoga svijeta".

Naše istraživanje pokazuje da - iako poigravanje jezikom i jezična zafrkancija jesu u temeljima stapanja kao tvorbenoga načina - stopljenice nisu nužno šaljivoga karaktera. Osim toga značenje stopljenica iz jezika reklama i medija veoma je često teško odrediti izvan konteksta novinarskoga teksta u kojem su upotrijebljene, odnosno izvan reklamne kampanje za čije su potrebe skovane.

\footnotetext{
${ }^{12}$ Riječ je zapravo o kalku prema engleskome modelu workaholic $(<$ work + alkoholic $)$.
} 
Glavni cilj reklamne industrije jest privući pozornost potrošača i nagovoriti ga na kupnju proizvoda. Stoga ne čudi da su stopljenice - kao tvorenice pri čijem stvaranju marketinški stručnjaci svojoj kreativnosti i ludizmu mogu dati maha - česte i kao imena proizvoda i kao dijelovi reklamnih slogana. Osim što svojim oblikom privlače pozornost potrošača, često se reklamna poruka može izreći jednom jedinom riječju.

Tako stopljenice freelika i freestupačan uporabom engleskoga pridjeva free u značenju 'besplatan' aludiraju na to da nije riječ o tek još jednoj dobroj prilici, već gotovo o besplatnoj prilici te da freestupačan internet nije samo cjenovno povoljan, već gotovo besplatan.

Imenom keksića krašotice (Kraš + krasotice) tvrtka Kraš osim što ističe vlastito ime, progovara i o visokoj kakvoći svojih keksića koji su prave krasotice.

Tvornica sladoleda Ledo poziva svoje klijente da budu kreativni poput Leonarda da Vincija i osmisle vlastitu kombinaciju sladoleda koji će se zvati Ledonardo (Ledo + Leonardo $)$.

Stara je strategija reklamne industrije uključivanje poznatih osoba u promidžbenu kampanju koje bi svojim imidžom trebale uvjeriti potrošače u kupnju proizvoda. Osim što je nogometaš Ivica Olić bio zaštitno lice reklamne kampanje jednoga teleoperatera, njegovo je ime uključeno i slogan kampanje Olićan (< Olić + odličan) internet kojim se insinuira da je internetska usluga koja se nudi brza, spretna, vješta poput omiljenoga igrača.

Dakle u jeziku reklama stopljenice se ponajprije rabe za privlačenje pozornosti potrošača i kratko (na razini jedne riječi) isticanje pozitivnih svojstava vlastitoga proizvoda, kao i isticanje imena tvrtke ili robne marke.

Naše istraživanje stopljenica u jeziku medija pokazalo je da se najčešće javljaju u tekstovima koji prema Tošoviću $(2002,250)$ pripadaju analitičkome ili književnopublicističkome stilu, tj. uglavnom ih nalazimo u kolumnama ili blogovima kao vrstama koje omogućuju najveću autorsku slobodu i stilsku individualnost u izričaju. Tematska analiza samih tekstova iz kojih su ekscerpirane stopljenice pokazala je da se u najvećem broju slučajeva radi o tekstovima koji se bave društveno-političkim zbivanjima, a novinari se stopljenicama kao rezultatima domišljatoga poigravanja jezikom služe ne bi li efektnije izrazili svoje (kritičke) stavove prema temama kojima se bave. 
Provedeno je istraživanje pokazalo i da je značenje stopljenica u publicističkome stilu često teško iščitljivo ne samo bez konteksta već i bez poznavanja društveno-političkih prilika.

Već smo govoreći o strukturama stopljenica spomenuli da ih je u našem korpusu potvrđen znatan broj nastao stapanjem osobnih imena. Tako su po uzoru na posuđenicu Brangelina ( $<$ Brad Pitt + Angelina Jolie) kojom se označuje poznati, glamurozni američki bračni par $^{13}$, u hrvatskome nastale stopljenice Dikolores $(<\text { Dikan Radeljak + Dolores Lambaša })^{14}$ i Faker (Fani Horvat + Željko Kerum). ${ }^{15}$

Samim činom stapanja imena poznatih parova aludira se i na posuđenu stopljenicu Brangelina i time na ,zvjezdani” status hrvatskih parova, eventualno uz blagi podsmijeh. ${ }^{16}$

Međutim stapanje osobnih imena nadišlo je svijet glamura i prenijelo se i u svijet politike, pa su u našem korpusu potvrđene i stopljenice Kara-

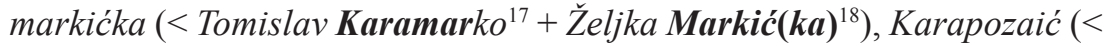
Tomislav Karamarko + Valentin Pozaic ${ }^{19}$ ), Karavaso ( $<$ Tomislav Karama$k o+$ Milijan Vaso Brkic $^{20}$ ) kojima se uvijek aludira na političku i interesnu povezanost osoba čija se imena stapaju. Uz uporabu takvih stopljenica vezana je veoma izražena kritika, često i grubo izrugivanje. Primjerice, tvorenicu Karapozaić prvi je upotrijebio zastupnik SDP-a Željko Jovanović (poslije se proširila elektroničkim medijima) koji je njome posprdno i kritički aludirao na zajedničke svjetonazorske stavove i političke ciljeve HDZ-a i Katoličke crkve.

$\mathrm{Na}$ zajedničke interese i spregu dvojice političara ukazuje se i tvore-

${ }^{13}$ Zanimljivo je da ta stopljenica već ima i status natuknice u Wikipediji (en.wikipedia. org/wiki/Brangelina; bs.wikipedia.org/wiki/Brangelina).

${ }^{14}$ Dikan Radeljak hrvatski je poduzetnik poznat i kao ljubitelj lijepih žena, a Dolores Lambaša bila je hrvatska glumica.

${ }^{15}$ Željko Kerum kontroverzni je splitski poduzetnik, bivši splitski gradonačelnik i saborski zastupnik, a Fani Horvat je njegova druga, znatno mlađa supruga.

${ }^{16}$ Tako se, primjerice, novinari 24 sata u naslovu zabrinuto pitaju Ante $i$ Simona gube bitku s Dikolores?, tj. je li Dikolores popularnošću prestigla do tada po skandalima vodeći hrvatski par iz svijeta poznatih Antu i Simonu Gotovac.

${ }^{17}$ Čelnik konzervativne stranke HDZ i prvi potpredsjednik Vlade. U našem je korpusu njegovo prezime najčešći dio stopljenica čijim je dijelom osobno ime.

${ }^{18}$ Čelnica katoličko-konzervativnoga pokreta $U$ ime obitelji.

${ }^{19}$ Pomoćni biskup zagrebački.

${ }^{20}$ Tajnik stranke HDZ. 
nicom Karavaso u tekstu vezanom uz plagirani diplomski rad Milijana Brkića u kojem se novinarka pita: „Što je to Karamarko dužan KaraVa$s i^{21}$ kad toliko brani jednog dokazanog prepisivača?" (www.novilist.hr, 29.03.2014).

Nakon što je otkrivena povezanost supruge Tomislava Karamarka $\mathrm{s}$ vrtkom $\mathrm{MOL}^{22}$, novinari su odmah osmislili i ime afere: KaraMOL (Karamarko $+\boldsymbol{M O L})^{23}$.

Bivšega ministra unutarnjih poslova Ranka Ostojića novinari su prozvali Rankozyjem ${ }^{24}$ u trenutku kada je spomenuo čestu umiješanost pripadnika romske manjine u kriminalne radnje, pa ga se novim nadimkom izjednačivalo s bivšim francuskim predsjednikom Sarkozyjem kritiziranim zbog deportacija Roma iz Francuske.

Na nečasnost političara Tomislava Karamarka aludira se i stopljenicom izrazito deprecijativnoga značenja Karamućak $(<\text { Karamarko }+ \text { mućak })^{25}$.

Podsmijeh političarima koji s nestrpljenjem iščekuju predizborne ankete, a potom se - ovisno o tome jesu li za njih povoljne ili ne - na njih pozivaju ili ih kritiziraju, sadržan je u stopljenici anketamini $(<$ anketa + amfetamini), čije bi se značenje moglo opisati kao 'anketa koja djeluje poput amfetamina'26.

Oštra kritika sadržana je u stopljenici katolibanija $(<\boldsymbol{k a t o l i c i}+$ talibanija) kojom je opisano gostovanje Željke Markić u televizijskoj emisiji Nedjeljom u 2 i kojom se aludira na njezine vjerske i svjetonazorske stavove koje autor teksta smatra ekstremnima i izjednačuje ih s onima talibana. $^{27}$

${ }^{21}$ Uporabom velikoga slova u ovome su primjeru istaknuti sastavni dijelovi stopljenice.

${ }^{22} \mathrm{RH}$ s tom tvrtkom trenutno vodi dva arbitražna postupka.

${ }^{23}$ „Štoviše, ponašanje HDZ-a u slučaju «KaraMOL» možemo smatrati samo logičnom posljedicom izostanka katarze u slučaju Sanader, jer je HDZ umjesto samokritike i ozbiljnog utvrđivanja raširenosti korupcije unutar stranke učinio sve da izolira Sanadera i pomete problem pod tepih, pri čemu svakako moramo imati na umu kako je za takav porazan ishod najodgovorniji upravo Karamarko, koji je stalno tvrdio da je stranka potpuno čista" (www. novilist.hr, 20.05.2016).

${ }^{24}$ www.novilist.hr, 30.03.2012.

${ }^{25}$ Osim što u hrvatskome jeziku imenica mućak znači pokvareno jaje ima i figurativno značenje pokvarene, nečasne osobe.

${ }^{26} \mathrm{U}$ članku naslovljenom Karamarko na anketaminima, www.novilist.hr, 5.01.2016.

${ }^{27}$ metro-portal.rtl.hr, 16.03.2016. 
Blagi podsmijeh lažnim intelektualcima izražen je stopljenicom snobelovac $(<$ snob + nobelovac $)$ čije bismo značenje mogli opisati kao 'snob koji knjige pojedinih autora počinje čitati tek kada postanu nobelovci' u primjeru: „Koliko su se kupci jagmili za novim nobelovcem i koliko je među njima bilo snobelovaca vidjelo se nakon dva-tri mjeseca, kada se u nekim knjižarama nije mogao pronaći prvi tom «Tumača», ali je zato drugoga toma bilo - vulgarno ali bukvalno - na bacanje" (www.novilist. hr, 13.10.2015).

Kritika naplaćivanja pristupa Svetoj potvrdi, Krizmi motivom je nastanka stopljenice katakrizma $(<(\text { financijska }) \text { kataklizma }+ \text { Krizma })^{28}$.

Analiza značenja stopljenica u publicističkome stilu potvrdila je da je riječ o tvorenicama ekspresivnoga značenja koje je često iščitljivo tek iz konteksta, a nerijetko je potrebno i poznavanje izvanjezične stvarnosti, tj. društvenih i političkih prilika na koje se odnose. ${ }^{29}$ To se osobito odnosi na stopljenice čijim su dijelom osobna imena jer bez poznavanja nositelja imena, njihova društvenoga položaja i svjetonazorskih stavova razumijevanje stopljenice nije moguće.

Humorističnost kao često isticano svojstvo stopljenica u našem korpusu nije izražena. Čak ako je i prisutna humoristična komponenta, obično je riječ o podsmijehu ili posprdnosti. Od humorističnosti mnogo su češće ironičnost, kritičnost ili deprecijativnost. Dapače na temelju analiziranoga korpusa može se zaključiti da novinari ovaj u hrvatskome jeziku relativno novi tvorbeni način koji pruža velike mogućnosti za poigravanje jezikom koriste ne bi li kratko i sažeto, na razini tek jedne nove riječi izrazili svoje (kritičke) stavove o temi o kojoj pišu. Osim što uporabom stopljenice isprva izazivaju čuđenje ili zbunjenost čitatelja i potiču ga na „dešifriranje" značenja novotvorbe, novinari veoma efektno iznose svoje stajalište. Mogli bismo čak reći da se u jeziku medija stopljenice često koriste kao riječi koncentrati jer se u samo jednoj riječi koncentrira autorov kritički stav. Stoga uporaba stopljenice ima znatno jači stilski efekt nego uporaba više riječi (anketamini umjesto anketa koje na političare djeluju poput amfetamina, snobelovac umjesto lažni intelektualac koji interes za pojedine autore počinje pokazivati tek kada postanu nobelovci).

${ }^{28}$ Članak je naslovljen Tarifa za katakrizmu, www.novilist.hr, 30.03.2012.

${ }^{29} \mathrm{O}$ figurativnome potencijalu složenica v. http://www.stilistika.org/bagic. 


\subsection{Mjesto stopljenica u leksičkome sustavu}

Za razliku od stopljenica kao što su figuar, škodilak, radoholičar koje su postale dijelom hrvatskoga leksika, tvorenice su iz našega korpusa prigodnice $^{30}$. Vesna Muhvić-Dimanovski $(2005,6)$ pišući o novotvorenicama u hrvatskome jeziku, razlikuje dva tipa neologizama: stilističke i denominativne. Stilistički neologizmi - u koje spadaju prigodnice - rabe se prigodno, u određenom kontekstu i imaju veoma male šanse da uđu u opću uporabu.

Irena Stramljič Breznik (2010b, 355) također vezanost za kontekst ističe kao jedno od glavnih obilježja okazionalizama koje je ujedno i razlogom zašto se ne leksikaliziraju.

Iako u kroatistici postoji i mišljenje da je glavno obilježje prigodnica potvrđenost u samo jednom izvoru, kod jednoga pisca $^{31}$, u slučaju novotvorenica iz našega korpusa to svojstvo izostaje. To je uvjetovano i prirodom korpusa i suvremenim telekomunikacijskim mogućnostima. Naime dovoljno je da jedan kolumnist u svojem tekstu upotrijebi osobito uspjelu stopljenicu ${ }^{32}$ i da tekst toga novinara prenesu i drugi elektronički mediji, pa da novu riječ počnu rabiti i čitatelji u svojim komentarima uz članke u elektroničkim izdanjima novina, korisnici foruma u svojim raspravama.

U jeziku reklamne industrije stopljenice se i stvaraju da bi ih se ponavljalo unutar jedne reklamne kampanje i da bi ih se zbog neobičnoga oblika u svijesti potrošača vezalo uz određeni proizvod ili robnu marku.

Dakle iako su potvrđene više od jedanput, stopljenice iz našega korpusa imaju druga obilježja prigodnica ${ }^{33}$ : jedinstvenost (i formalnu i značenjsku), osobitu funkciju koja se ostvaruje kao koncentracija informacija i ostvarivanje posebnih stilskih efekata, ovisnost o kontekstu (na razini članka, u društveno-političkom kontekstu ili u reklamnoj kampanji) i neleksikaliziranost. Upravo neleksikaliziranost čini glavnu razliku u odnosu

${ }^{30} \mathrm{U}$ kroatistici se kao istoznačnice rabe i nazivi hapaks, okazionalizam.

${ }^{31}$ Simeon $(1969,957)$ hapaks definira kao ,riječ, oblik, uporabu za koju imamo samo jedan primjer kod pisaca (osobito starih) ili u pojedinoga pisca”.

${ }^{32}$ Uspjelu u smislu da je čitatelji i kolege novinari ocijene kao duhovitu, osobito pogodnu za izražavanje određenoga stava, osobito kritičku.

${ }^{33}$ Prema Tomášikova $(2008,247)$. 
na neologizme. ${ }^{34}$ Ukoliko neologizme definiramo kao leksikalizirane, a prigodnice kao neleksikalizirane elemente, tada moramo prihvatiti da između njih postoji veoma široko prijelazno područje. Naime hoće li se prigodnica leksikalizirati ili neće ovisi o nizu čimbenika kao što su potreba za takvim označiteljem, tvorbena regularnost prigodnice, odnos prema konkurentskim označiteljima. Veoma važan čimbenik pri razgraničenju prigodnica od neologizama jest i vrijeme. Wolfgang Teubert $(1998,134)$ govori o paradoksu da se u germanistici kao jedan od glavnih kriterija za razlikovanje prigodnica i neologizama smatra „novost” jer ističe da se o neologizmu može govoriti tek kada se određena riječ u određenom korpusu rabi duže vrijeme i s većom učestalošću, što znači da zapravo više nije nova.

Smatramo da su izgledi da se stopljenice iz našega korpusa leksikaliziraju iznimno male upravo zbog njihove tvorbene neobičnosti, izrazite stilske obojenosti i vezanosti uz određeni kontekst. Dovoljno je s pomoću internetskih tražilica potražiti potvrde za neke od starijih stopljenica iz našega korpusa (npr. Rankozy, Olićan, Sretan Čoksić) i ustanovit ćemo da posljednje potvrde potječu od prije nekoliko godina.

\section{Zaključak}

Stopljenice kao tvorenice nastale formalnim i značenjskim stapanjem (najčešće) dviju riječi posljednjih desetak godina veoma su učestale $\mathrm{u}$ hrvatskome jeziku. S jedne je to strane posljedica utjecaja engleskoga kao globalnoga jezika, a s druge strane novih izražajnih mogućnosti koje takve tvorenice pružaju. Zbog svoje ekspresivnosti uglavnom su vezane za jezik reklama i jezik medija.

Struktura stopljenica ne počiva na morfemskoj raščlambi riječi, već na proizvoljnom izdvajanju i stapanju dijelova dviju ili rjeđe više riječi. U hrvatskome su jeziku potvrđene sljedeće strukture stopljenica: stopili su se prvi dio prve i drugi dio druge riječi (Viktator $<$ Viktor Orban + diktator), prvi dio prve riječi i cijela druga riječ (Karamućak $<$ Karamarko + mućak), cijela prva riječ i drugi dio druge riječi (freelika $<$ free + prilika) te cijela prva i cijela druga riječ (sprinternet $<$ sprint + internet).

${ }^{34}$ v. Fleischer i Barz $(1995,24)$. 
U jeziku reklama dijelom stopljenica često je ime tvrtke ili robne marke (krašotice $<$ Kraš + krasotice, Ledonardo $<$ Ledo + Leonardo), dok su u jeziku medija česte stopljenice čijim je dijelom osobno ime (Dikolores $<$ Dikan + Dolores).

Uporabom stopljenica u jeziku reklama nastoji se privući pozornost potrošača te ih se takvom reklamnom porukom koncentriranom $u$ jednu riječ uvjeriti u prednosti reklamiranoga proizvoda i potaknuti na kupnju.

$\mathrm{U}$ jeziku medija stopljenice nalazimo u kolumnama i blogovima, tj. vrstama koje pružaju najveću autorsku slobodu. Novim oblicima autori se koriste za efektno izražavanje vlastitih stajališta prema društveno-političkim zbivanjima, pa je značenje stopljenica u novinarskim tekstovima često veoma teško iščitljivo bez konteksta i bez poznavanja društveno-političkih prilika.

Upravo zbog vezanosti za kontekst stopljenice iz našega korpusa prigodnice su i smatramo da njihova leksikalizacija ${ }^{35}$ nije izgledna ${ }^{36}$. Međutim, zbog mogućnosti koje stopljenice kao relativno novi tip tvorenica pružaju, zbog njihova jedinstvenoga spoja forme i sadržaja smatramo da će se i dalje intenzivno upotrebljavati u hrvatskome jeziku medija i reklama.

\section{Literatura}

Avramova, C. (2012). Sobstvenite imena kakto resurs za obrazuvane na novi dumi v suvremenija blgarski knjižoven ezik. U: Tvorba riječi i njeni resursi u slovenskim jezicima. Zbornik radova sa četrnaeste međunarodne naučne konferencije Komisije za tvorbu reči pri Međunarodnom komitetu slavista. Ur. B. Ćorić, R. Dragićević. Beograd: Filološki fakultet Univerziteta u Beogradu, str. 21-33.

Bagić, K. (2015). Stopljenica: riječ, figura, kultura. U: Svijet stila, stanja stilistike. Zbornik radova prezentiranih na istoimenom kolokviju održanom 13. veljače 2015. na Filozofskom fakultetu u Zagrebu. http://stilistika.org/svijet-stila-stanja-stilistike. 23.09.2017.

Bugarski, R. (2002). Dve reči u jednoj: leksičke skrivalice. U: R. Bugarski. Nova lica jezika. Beograd: Biblioteka XX vek, Knjižara Krug, str. 219-227.

Bugarski, R. (2013). Sarmagedon u Mesopotamaniji. Beograd: Biblioteka XX vek.

${ }^{35}$ Leksikalizacija u smislu uvrštavanja u leksik nekoga jezika, tj. postajanja dijelom leksika nekoga jezika (Simeon 1969, 754; Glück, 2000, s. v. Lexikalisierung).

${ }^{36}$ Bagić (2015.) naglašava da su stopljenice ,manje jezična a više govorna, diskurzivna činjenica”. 
Elsen, H. (2004). Neologismen. Formen und Funktionen neuer Wörter in verschiedenen Varietäten des Deutschen. Tübingen: Günter Narr.

Fleischer, W. (1988). Produktivität-Akzeptabilität-Aktivität. Zur Theorie der Wortbildung (im Deutschen). U: W. Fleischer. Zur Theorie der Wortbildung im Deutschen. Berlin: Akademie Verlag, str. 8-18.

Fleischer, W., Barz I. (1995). Wortbildung der deutschen Gegenwartssprache. Tübingen: De Gruyter.

Glück, H. (ur.) (2000). Metzler Lexikon Sprache. Digitale Bibliothek 34. Stuttgart: Metzler Verlag.

Gries, S.T. (2004). Shouldn't it be breakfunch?: A quantitative analysis of blend structure in English. „Linguistics”, br. 42-43, str. 639-667.

Hohenhaus, P. (1996). Ad-hoc-Wortbildung. Terminologije, Typologie und Theorie kreativer Wortbildung im Englischen. Frankfurt am Main: Peter Lang.

Horvat, M., Štebih Golub, B. (2015). Tvorenice motivirane osobnim imenom u jeziku hrvatskih medija. U: Jezik medija nekada i sada. Zbornik radova sa znanstvenoga skupa održanoga 6. i 7. lipnja 2014. godine na Filozofskom fakultetu u Osijeku. Ur. V. Rišner. Zagreb: Hrvatska sveučilišna naklada, str. 217 -236.

Koriakowcewa, E. (2006). O slavoobrazovatelnoj kompresiji (na materijale ruskovo i poljskovo jazikov). U: Funkcionalni aspekti tvorbe. Ur. A.A. Lukašanec. Minsk: VTAA Prava i ekonomika, str. 122-131.

Košćak, N. (2015). Grafostilistika i politika. U: Svijet stila, stanja stilistike. Zbornik radova prezentiranih na istoimenom kolokviju održanom 13. veljače 2015. na Filozofskom fakultetu u Zagrebu. http://www.stilistika.org/koscak. 23.09.2017.

Krieg, U. (2005). Wortbildungsstrategien in der Werbung. Zur Funktion und Struktur von Wortneubildungen in Printanzeigen. Hamburg: Buske.

Lewis, K., Štebih Golub, B. (2014). Tvorba riječi i reklamni diskurs. „Rasprave: Časopis Instituta za hrvatski jezik i jezikoslovlje", br. 40/1, str. 133-147.

Logar, N. (2004a). Nove tehnologije in nekateri nesistemski besedotvorni postopki. $\mathrm{U}$ : Aktualizacija jezikotvorne teorije na Slovenskem: členitev jezikovne resničnosti. Obdobja 22. Ur. E. Kržišnik. Ljubljana: Univerza v Ljubljani. str. 121-132.

Logar Berginic, N. (2004b). Nove tvorjenke v publicistiki. U: Poti slovenskega novinarstva - danes in jutri. Znanstveni zbornik ob 40. obletnici študija novinarstva na Slovenskem. Ur. K. Golob, M. Poler Kovačič. Ljubljana: Fakulteta za družbene vede, str. $174-199$.

Marković, I. (2009). Tri nehrvatske tvorbe: infiksacija, reduplikacija, fuzija. „Rasprave Instituta za hrvatski jezik i jezikoslovlje”, br. 35, Zagreb: Institut za hrvatski jezik i jezikoslovlje, str. 217-241.

Marković, I. (2011). Hrvatske stopljenice. Novina u slengu, jeziku reklame i novina. U: Diskurs i dijalog: Teorije, metode i primjene. Ur. V. Karabalić et al. Osijek: Filozofski fakultet Sveučilišta u Osijeku, str. 223-238.

Marković, I. (2013). Uvod u jezičnu morfonologiju. Zagreb: Disput.

Marković, I., Klindić, I., Borković, I. (2016). Hrvatski rječnik stopljenica. http://stilistika.org/hrvatski-rjecnik-stopljenica. 23.09.2017. 
Muhvić-Dimanovski, V. (2005). Neologizmi. Problemi teorije i primjene. Zagreb: Zavod za lingvistiku filozofskoga fakulteta.

Otašević, Đ. (2008). Nove reči i značenja u savremenom standardnom srpskom jeziku. Beograd: Alma.

Simeon, R. (1969). Enciklopedijski rječnik lingvističkih naziva. Zagreb: Matica hrvatska.

Stramljič Breznik, I. (2010a). Tvorjenke slovenskega jezika med slovarjem in besedilom. Maribor: Univerza v Mariboru.

Stramljič Breznik, I. (2010b). Besedotvorne lastnosti slovenskih okazionalizmov. U: Novye javlenija v slavjanskom slovoobrazovanii: sistema i funkcionirovanie: trudy $i$ materialy , Slavjanskie jazyki i kultury v sovremenom mire”. Ur. E. Vasilevna Petruhina. Moskva: Moskovskij gosudarstvennyj universitet imeni M.V. Lomonosova, Filologičeskij fakultet, str. 352 -363.

Stramljič Breznik, I. (2012). Tipološki in funkcijski vidik novotvorjenk v slovenskih oglasih. U: Stowotwórstwo słowiańskie: system i tekst. Prace Komisji Słowotwórczej przy Międzynarodowym Komitecie Slawistów, seria 13. Ur. J. Sierociuk. Poznań: Wydawnictwo Poznańskiego Towarzystwa Przyjaciół Nauk, str.113-123.

Štebih Golub, B. (2012). Okazionalizmi u hrvatskome publicističkom stilu. U: Tvorba reči $i$ njeni resursi u slovenskim jezicima. Zbornik radova sa četrnaeste međunarodne naučne konferencije Komisije za tvorbu reči pri Međunarodnom komitetu slavista. Ur. B. Ćorić, R. Dragićević. Beograd: Filološki fakultet Univerziteta u Beogradu, str. 419-437.

Teubert, W. (1998). Korupus und Neologie. U: Neologie und Korpus. Studien zur deutschen Sprache, br. 11. Ur. W. Teubert. Tübingen: Günter Narr, str. 129-170.

Tomášiková, S. (2008). Okkasionalismen in den deutschen Medien. U: Médiá a text II. Ur. M. Bočák, Prešova: Filozofická fakulta Prešovskej univerzity v Prešove, str. 246-256.

Tošović, B. (2002). Funkcionalni stilovi. Graz: Institut für Slawistik der Karl-Franzens-Universität Graz. 